\title{
Reframing faculty development practice and research through the lens of adaptive expertise
}

Citation for published version (APA):

Steinert, Y., Irby, D. M., \& Dolmans, D. (2021). Reframing faculty development practice and research through the lens of adaptive expertise. Medical Teacher, 43(8), 865-867.

https://doi.org/10.1080/0142159x.2021.1931081

Document status and date:

Published: 03/08/2021

DOI:

10.1080/0142159x.2021.1931081

Document Version:

Publisher's PDF, also known as Version of record

Document license:

Taverne

Please check the document version of this publication:

- A submitted manuscript is the version of the article upon submission and before peer-review. There can be important differences between the submitted version and the official published version of record.

People interested in the research are advised to contact the author for the final version of the publication, or visit the DOI to the publisher's website.

- The final author version and the galley proof are versions of the publication after peer review.

- The final published version features the final layout of the paper including the volume, issue and page numbers.

Link to publication

\footnotetext{
General rights rights.

- You may freely distribute the URL identifying the publication in the public portal. please follow below link for the End User Agreement:

www.umlib.nl/taverne-license

Take down policy

If you believe that this document breaches copyright please contact us at:

repository@maastrichtuniversity.nl

providing details and we will investigate your claim.
}

Copyright and moral rights for the publications made accessible in the public portal are retained by the authors and/or other copyright owners and it is a condition of accessing publications that users recognise and abide by the legal requirements associated with these

- Users may download and print one copy of any publication from the public portal for the purpose of private study or research.

- You may not further distribute the material or use it for any profit-making activity or commercial gain

If the publication is distributed under the terms of Article $25 \mathrm{fa}$ of the Dutch Copyright Act, indicated by the "Taverne" license above, 


\title{
COMMENTARY
}

\section{Reframing faculty development practice and research through the lens of adaptive expertise}

\author{
Yvonne Steinert ${ }^{\mathrm{a}}$, David M. Irby ${ }^{\mathrm{b}}$ (D) and Diana Dolmans ${ }^{\mathrm{c}}$ (D) \\ ${ }^{a}$ Institute of Health Sciences Education, Faculty of Medicine \& Health Sciences, McGill University, Montreal, Canada; ${ }^{\mathrm{b}}$ Medicine, \\ University of California, San Francisco, San Francisco, CA, USA; 'Department of Educational Development and Research, Faculty of \\ Health, Medicine, and Life Sciences, Maastricht University, Maastricht, Netherlands
}

Leaders in academic medicine have observed that 'the goal of faculty development is to provide faculty members with the skills relevant to their institutional setting and faculty position, and to sustain their vitality, both now and in the future' (Whitcomb 2003). At no time, has this intent been more evident.

This special issue of Medical Teacher was written and published during a global pandemic, a time in which we witnessed a significant decrease in face-to-face social interactions, health care systems that were stretched to their limits, governments that struggled to find a balance between the health of their populations and the collapse of their economies, and colleagues worldwide living in an atmosphere of fear and uncertainty. We also witnessed an enduring commitment to educating the next generation of health professionals and basic scientists, a collective will to adapt educational curricula to online platforms, and a profound desire to help our faculty members cope with uncertainty and change. This has been a time of deep introspection, collective learning, and a sustained willingness to adapt to the world around us - and faculty development has played a central role.

In this commentary, we provide an overview of this issue of Medical Teacher, after which we focus on reframing faculty development practice and research through the lens of adaptive expertise.

\section{Overview of this special issue}

In many ways, this special issue marks the recognition of faculty development as a critical component of medical education. Over the last decade, we have seen a notable increase in the scholarly output and development of this field, with an enhanced focus on research and innovation around the world; and this special issue sheds light on some of these developments. To create this issue, we circulated a special call to the AMEE community for research papers and innovation reports related to faculty development that would be of interest to an international audience. We tried to disseminate the call as widely as possible, to ensure an inclusive and international collection of articles that would focus on the diverse aspects of faculty development, including teaching enhancement, leadership development, and research capacity-building (Steinert 2014). And we were not disappointed; we received over
100 submissions from around the world. How the field has grown!

We were also very pleased that we could include a section on Innovation Reports. Inspired by the Really Good Stuff section of Medical Education, and cognizant of the fact that faculty developers are often driven by a desire to innovate and respond to community needs, we wanted to be able to showcase this work. We also wanted to promote reflection on the value of innovation in driving individual growth, new knowledge, and organizational development. We hope that the enclosed innovation reports, on topics ranging from building agency to educator identity, from clinical supervision to student engagement in health professions education, and from narrative medicine to simulation-based education, to name only a few, will meet that goal. We also hope that Medical Teacher will consider adding this feature to future issues, to enable the sharing of creative thinking in a brief and focused manner.

The research papers in this issue cover a broad range of faculty development topics and issues, from exploring the nature of informal learning, mentorship, leadership, and professional identity, to examining faculty development from an organizational lens. These articles also underscore the critical importance of theory in informing research and practice as well as a significant shift in research methodologies, moving from quantitative to qualitative research designs. In addition, these research papers describe faculty development in different countries and cultures, further highlighting the role of context in faculty development as well as the social components of ongoing professional development.

Thus, the six research papers and twelve innovation reports, from five continents, demonstrate that faculty developers are continuously searching for ways to better understand and optimize faculty development. They also show that faculty development practices not only focus on knowledge acquisition but also promote the application of this knowledge in a variety of contexts as well as the ability to be nimble, creative and proactive in adapting to change. In fact, in multiple ways, these publications underscore how faculty development is a striking example of promoting adaptive expertise at many levels. That is, both faculty members and faculty developers need to demonstrate the ability to adapt to novel, uncertain or complex situations while maintaining their competence in routine 
circumstances (Baker et al. 2018; Mylopoulos, Kulasegaram, et al. 2018).

\section{What is adaptive expertise?}

Adaptive expertise in health professions education has most often been linked with clinical expertise - and with clinical reasoning in particular (Mylopoulos and Woods 2017; Kua et al. 2021). However, adaptive expertise also has a significant role to play in medical education more broadly, and in faculty development specifically.

Adaptive expertise encompasses both innovation and efficiency at the individual and the organizational level (Pusic et al. 2018). Often contrasted with routine expertise, in which individuals use their knowledge effectively and efficiently, adaptive expertise enables individuals to construct new solutions when faced with novel problems (Schwartz et al. 2005). As Mylopoulos, Kulasegaram et al. (2018) have stated, 'adaptive expertise emphasizes the flexible use of knowledge and the ability to generate new solutions and learn from daily problem solving'. That is, individuals with adaptive expertise demonstrate the ability to access their interconnected knowledge networks fluidly and flexibly to push boundaries, be creative, and foster innovation; their knowledge representations are also more malleable, allowing them to respond to novel situations more effectively (Schwartz et al. 2005). Thus, individuals who demonstrate adaptive expertise are able to balance the efficient and effective use of their previously acquired knowledge in response to novelty and complexity (Gube and Lajoie 2020) - a key goal in faculty development that has been accentuated even more during the pandemic.

\section{Implications of adaptive expertise for faculty development practice}

The innovation reports and research papers in this themed issue demonstrate that faculty developers aim to inspire health professionals to create new solutions to problems they encounter in their teaching contexts. Additionally, the innovations illustrate how health professionals are encouraged to advance their educational practices by engaging collaboratively in new or existing communities, helping to promote creativity and joint problem-solving. They also highlight how health professionals work together on authentic projects, informed by experience and insights from scientific evidence, to re-invent and innovate their routine practices, implement new activities, or evaluate anticipated outcomes.

Mylopoulos, Kulasegaram et al. (2018) highlighted three principles that underpin educational programs aiming to enhance adaptive expertise. They include: promoting understanding rather than performance; emphasizing struggle and risk-taking leading to discovery; and maximising opportunities to experience meaningful variation in learning to expand knowledge across multiple contexts. That is, learners at all levels need to be encouraged to work through complex scenarios, in both formal training contexts and in clinical practice, in order to maximize learning (Baker et al. 2018). Mylopoulos, Steenhof et al. (2018) also outlined specific teaching approaches, such as integrating conceptual knowledge and focusing on 'why' questions to reinforce cognitive integration, offering a varied set of experiences to cultivate long-term learning in addition to short-term success, and allowing for experimentation and failure to uncover new ways of knowing. These features should also characterize faculty development programs and activities. That is, faculty development programs should aim to emphasize the 'why' of what faculty members do in addition to the 'how', encourage individuals to enhance their understanding of how knowledge can be transferred to novel situations, and offer participants a varied set of experiences to apply their knowledge with the goal of exploring, rethinking and reinventing their practices.

The authors of the innovation reports and research papers in this special issue have shared their successes, situated in their own contexts. We have also encouraged them to explain their struggles, which are often less well explained in the literature. Training for adaptive expertise allows faculty members and faculty developers to experiment and discover why certain knowledge works well in a particular context or why it cannot be transferred to another setting. With this objective in mind, we should encourage health professionals to explore, experiment, make errors (Gube and Lajoie 2020), and share lessons learnt if proposed solutions fail (Steenhof et al. 2020). We should also encourage colleagues to investigate if their innovations are scalable and have sustainable longterm impacts.

\section{Implications of adaptive expertise for faculty development research}

The research papers in this special issue demonstrate how the field has evolved, with an increased focus on the social aspects of faculty development, the importance of an educator identity, and the role of leadership and the organization at large. The research papers also suggest that faculty development practices do not focus solely on knowledge acquisition, but also stress the importance of participating in a social community in which members interact with, and learn from, each other. In addition, these articles demonstrate that diverse theoretical frameworks (e.g. socialization theory; threshold concepts; practice architectures) are being used, and that we have moved from quantitative to qualitative methodologies, paving the way forward for mixed-methods studies.

As demonstrated in the current health care crisis, there is no one-size-fits-all solution to address the challenges we face in our society. The same holds true for research in faculty development. As researchers in this field, we need to show that we can move beyond routine expertise and demonstrate adaptive expertise as needed, and that we can embrace a variety of current and emerging theories and methodologies in our scholarly activities. We also have to demonstrate that, as researchers, we are able to focus on understanding why and under which conditions certain theories or methodologies can be used, take risks, and expand our knowledge across settings and contexts. One way to do this is to embrace design-based research, which uses a mixed-methods approach and offers opportunities to gain a better understanding about why a particular practice, characterized by certain theoretical design principles, might work under specific conditions (Dolmans and 
Tigelaar 2012). Educational design research also aims to develop theoretical insights and practical solutions simultaneously, in close collaboration with stakeholders (McKenney and Reeves 2021). In addition, future research should investigate how adaptive expertise has been incorporated into faculty development programs and activities, and explore what new avenues and implications this direction might hold for research and practice.

In summary, there are no universal practical solutions, theories or methodologies that can work under all conditions. However, we do need to design faculty development practices and research that aim to enhance - and incorporate - adaptive expertise.

Cutrer et al. (2018) have described four characteristics that foster adaptive expertise and can help to nurture vitality: curiosity, mindset, motivation and resilience. We believe that faculty members and faculty developers - and the authors of these research papers and innovation reports demonstrate these characteristics and more!

The goal of this commentary is to suggest a reframing of faculty development through the lens of adaptive expertise. The advancement of adaptive expertise requires a learning process that challenges assumptions, incorporates ambiguity, and rewards experimentation (Christensen 2006). By reconceptualizing faculty development, we encourage faculty developers to consider new ways of designing professional development, with the goal of promoting faculty members' adaptive expertise, and expand their research agenda by exploring novel questions, incorporating theory, and utilizing diverse methodologies. Incorporating the framework of adaptive expertise into our work might also help to explain the why of faculty development.

\section{Acknowledgements}

We would like to thank the editorial committee members of this special issue, Trevor Gibbs, Susan van Schalkwyck, Karen Leslie, Olanrewaju Sorinola, Harm Peters, Manuel Mendes Costa, Eliana Amaral, Haruko Akatsu and Tripti Srivastava, for their selection and review of the innovation reports and research papers; Subha Raman and Michelle Machado for their help in the review process; and Manon Kluijtmans and Susan van Schalkwyck for their insightful feedback on this commentary.

\section{Disclosure statement}

The three authors do not have a declaration of interest to report.

\section{Notes on contributors}

Yvonne Steinert, $\mathrm{PhD}$, is a professor of Family Medicine and Health Sciences Education, former director of the Institute of Health Sciences Education, and the Richard and Sylvia Cruess Chair in Medical Education, Faculty of Medicine and Health Sciences, McGill University, Montreal, Canada. She is also co-editor of this special issue.
David M. Irby, PhD, MDiv, is professor emeritus of Medicine and an educational scientist in the Center for Faculty Educators at University of California San Francisco. He was formerly the vice-dean for education at UCSF and a senior scholar at The Carnegie Foundation for the Advancement of Teaching.

Diana H. J. M. Dolmans, $\mathrm{PhD}$, is professor of innovative learning arrangements and educational scientist in the School of Health Professions Education (SHE), and chair of the Department of Educational Development \& Research, Faculty of Health, Medicine and Life Sciences, Maastricht University, The Netherlands. She is also coeditor of this special issue.

\section{ORCID}

David M. Irby (iD http://orcid.org/0000-0001-5753-8918

Diana Dolmans (iD http://orcid.org/0000-0002-4802-1156

\section{References}

Baker L, Leslie K, Panisko D, Walsh A, Wong A, Stubbs B, Mylopoulos M. 2018. Exploring faculty developers' experiences to inform our understanding of competence in faculty development. Acad Med. 93(2):265-273.

Christensen CM. 2006. The ongoing process of building a theory of disruption. J Product Innovation Man. 23(1):39-55.

Cutrer WB, Atkinson HG, Friedman E, Deiorio N, Gruppen LD, Dekhtyar M, Pusic M. 2018. Exploring the characteristics and context that allow master adaptive learners to thrive. Med Teach. 40(8):791-796.

Dolmans DH, Tigelaar D. 2012. Building bridges between theory and practice in medical education using a design-based research approach: AMEE Guide No. 60. Med Teach. 34(1):1-10.

Gube M, Lajoie S. 2020. Adaptive expertise and creative thinking: a synthetic review and implications for practice. Think Skills Creat. 35 100630.

Kua J, Lim W-S, Teo W, Edwards RA. 2021. A scoping review of adaptive expertise in education. Med Teach. 43(3):347-355.

McKenney S, Reeves TC. 2021. Educational design research: portraying, conducting, and enhancing productive scholarship. Med Educ. 55(1):82-92.

Mylopoulos M, Kulasegaram K, Woods NN. 2018. Developing the experts we need: fostering adaptive expertise through education. J Eval Clin Pract. 24(3):674-677.

Mylopoulos M, Steenhof N, Kaushal A, Woods N. 2018. Twelve tips for designing curricula that support the development of adaptive expertise. Med Teach. 40(8):850-854.

Mylopoulos M, Woods NN. 2017. When I say... Adaptive expertise. Med Educ. 51(7):685-586.

Pusic MV, Santen SA, Dekhtyar M, Poncelet AN, Roberts NK, WilsonDelfosse AL, Cutrer WB. 2018. Learning to balance efficiency and innovation for optimal adaptive expertise. Med Teach. 40(8): 820-827.

Schwartz DL, Bransford JD, Sears D. 2005. Efficiency and innovation in transfer. In Mestre JP, editor. Transfer of learning from a modern multidisciplinary perspective. Charlotte (NC): Information Age Publishing; p. 1-51.

Steenhof N, Woods NN, Mylopoulos M. 2020. Exploring why we learn from productive failure: insights from the cognitive and learning sciences . Adv Health Sci Educ Theory Pract. 25(5):1099-1106.

Steinert Y, editor. 2014. Faculty development in the health professions: a focus on research and practice. Dordrecht (Netherlands): Springer Publishing.

Whitcomb ME. 2003. The medical school's faculty is its most important asset. Acad Med. 78(2):117-118. 